Historic, Archive Document

Do not assume content reflects current scientific knowledge, policies, or practices. 



\section{Fall Catalogue 1913}

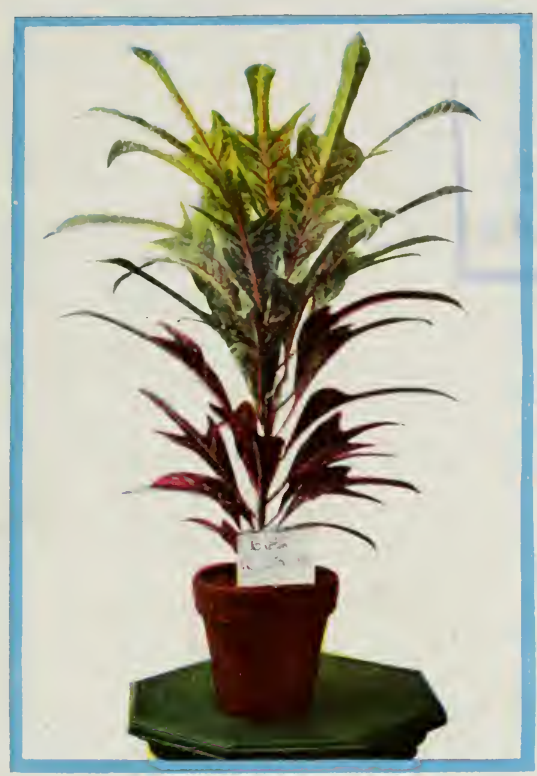

Croton Norwood Beauty

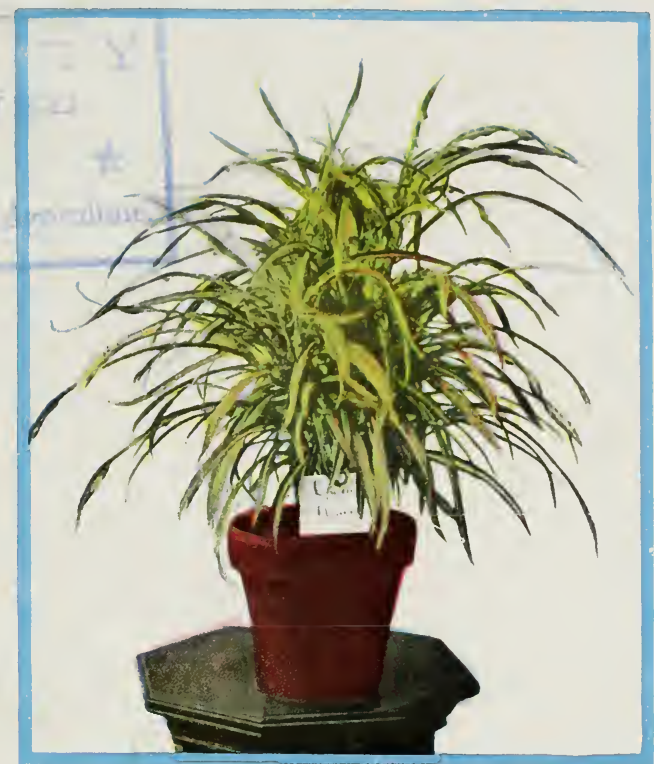

Croton Florence

\section{ROBERT CRAIG COMPANY 4900 Market Street Philadelphia, Pa.}

BRANCH-NORWOOD, PENNSYLVANIA

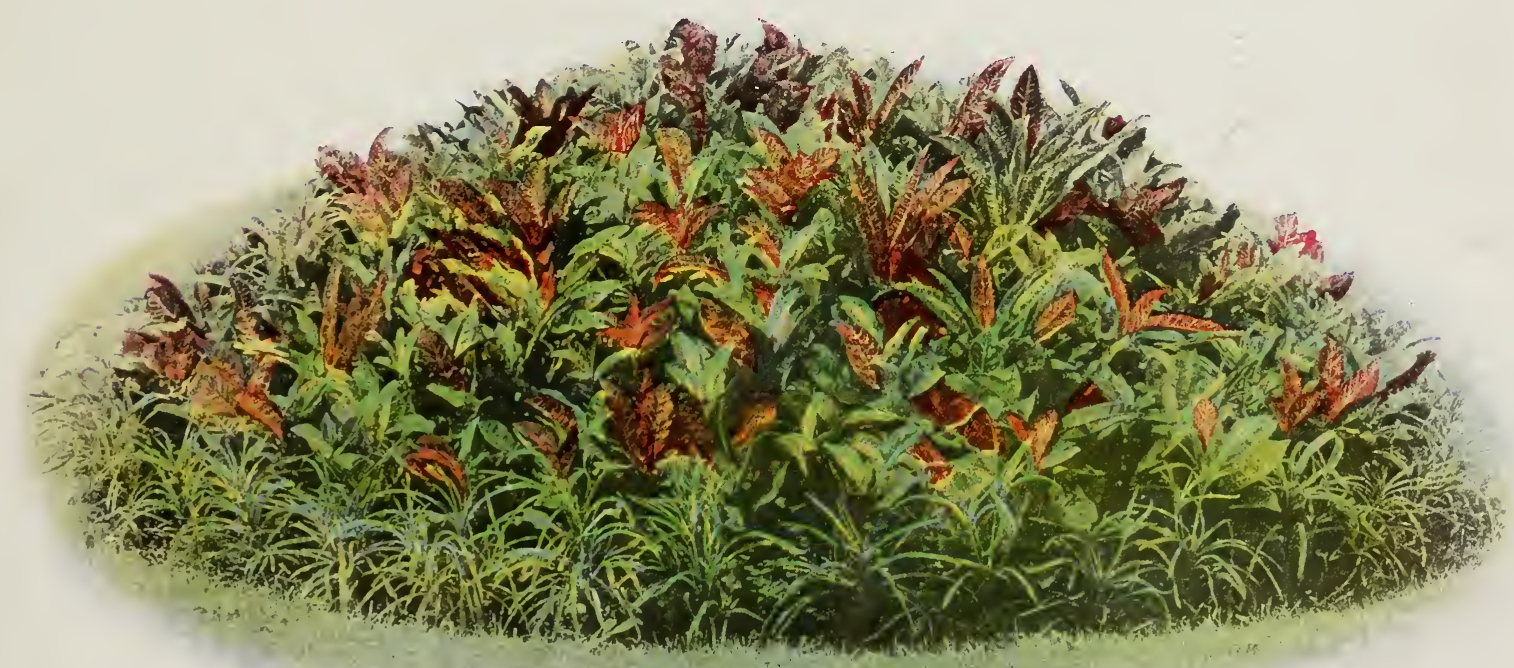




\section{To Our Customers}

CRAIG SPECIALTIES are known all over the country and are in greater demand each year. Having increased our glass area over 100,000 square feet, we are in a position to meet our fast increasing business. Our stock for the fall season is superior in quality to any we have ever grown, notwithstanding the high standard we have maintained for years. Any buyer seeking quality will be repaid by inspecting our immense stock at both our Philadelphia and Norwood establishments.

We extend to all a very cordial invitation to call, feeling assured your visit will be both a pleasure and a profit. If unable to call you may send us your order, large or small, with every confidence that it will have our best attention. We would suggest placing your orders as early as possible.

\section{TERMS :-}

CASH WITH ORDER. Kindly send sufficient to cover the entire bill. We do not make shipments C. O. D. unless remittance has been made on account to guarantee acceptance. This does not apply to regular customers.

REMITTANCES:-Remittances should be made by money order or New York drafts. If money is sent, letter should be registered. All prices quoted in this list are strictly net.

SHIPPING INSTRUCTIONS :-Give your name, post office, county and state, and the name of your nearest express office to which shipment is to be made.

CORRESPONDENCE :-We endeavor to answer all correspondence promptly, but owing to the pressure of business during the Fall we ask that all requests be clearly and concisely stated.

ERRORS :- Keep a copy of your order. We aim to have our orders correctly filled. Where we are at fault we shall make satisfactory correction. 


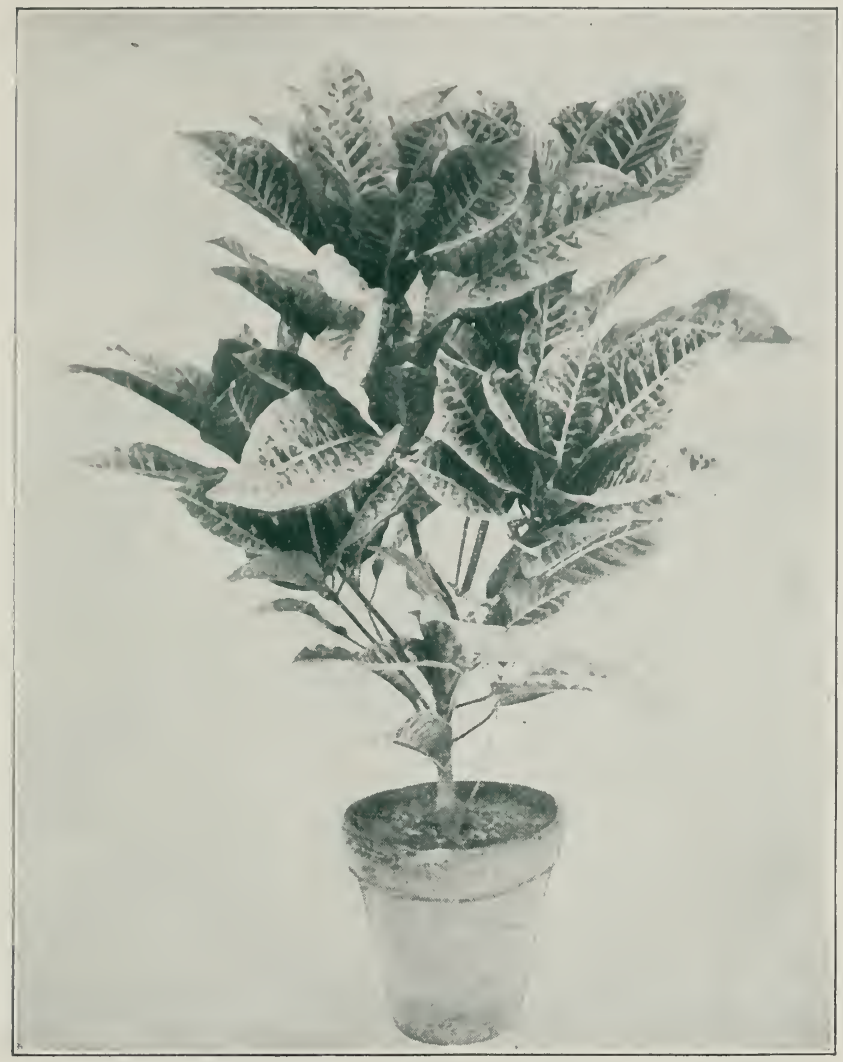

\section{CROTONS}

\section{CROTONS}

The Croton with its highly-colored foliage is indispensable during fall and winter. We have the largest and most complete collection of Crotons in the world, carrying at the present time for fall sales over 100,000 plants in over 400 varieties, all of the very highest quality and brilliantly colored.

$21 / 2$-inch pots, strong plants,

4 -inch pots, strong plants,

$\$ 20$ per $100 ; \$ 175$ per 1,000

5 -inch pots, strong plants,

$\$ 30$ per $100 ; \$ 275$ per 1,000

6 -inch pots, strong plants,

$\$ 12, \$ 15, \$ 18$ and $\$ 24$ per doz.

7 -inch pots, strong plants,

$\$ 24, \$ 30$ and $\$ 36$ per doz.

8 -inch pots, made up beautiful plants,

$\$ 24, \$ 30$ and $\$ 36$ per doz.

10 -inch pots, made up beautiful plants,

$\$ 5, \$ 6$ and $\$ 7.50$ each

12 -inch and 14-inch tubs, made up beautiful

plants................\$10, $\$ 15$ and $\$ 20$ each

Every retail store and grower should feature Crotons this fall and winter. We know our stock will please you and your customers.

\section{CROTON PUNCTATA}

One of the finest and most satisfactory varieties for basket work and centers of ferneries.

$21 / 2$-inch pots . . . . . . \$ $\$ 8$ per $100 ; \$ 75$ per 1,000 3 -inch pots . ............ \$20 per 100; $\$ 150$ per 1,000 4 -inch pots ........... \$25 per 100; $\$ 225$ per 1,000

8 -inch pots, made up .......\$18 and $\$ 24$ per doz.

\section{CROTON NORWOOD BEAUTY}

This variety is one of the best of our seedlings, raised three years ago, and we are now in a position to offer same in quantity and at very reasonable prices. This variety has an oak-shaped leaf and is brilliantly colored red, yellow and orange.

4 -inch pots, heavy ............. \$50 per 100 6 -inch pots, heavy ..............\$18 per doz.

\section{CROTONS-Narrow Leaf Types \\ DELICATISSIMA, GOLDEN THREAD AND FLORENCE}

These varieties are indispensable for table decoration and we predict a great future for them as nothing surpasses them for use in artistic arrangement.

4 -inch pots . .................. \$30 per 100 5 -inch pots ................. $\$ 50$ and $\$ 75$ per 100 6 -inch pots .......... \$12, $\$ 15$ and $\$ 18$ per doz. 


\section{NEW SEEDLING VARIETIES}

Our new Seedling Crotons, some of which we disseminated in June, 1911, are varieties that should be in every grower's and private person's collection. They are far superior to many of the older varieties of Crotons and the types range from narrow to very large leaf.

We particularly call your attention to our set of thirteen, named after the "Thirteen Original States," which have won highest honors wherever shown.

4-inch pots, strong plants,

$\$ 3$ each, $\$ 30$ per doz., $\$ 200$ per 100 6-inch and 7 -inch pots, larger plants, $\$ 3.50, \$ 4$ and $\$ 5$ each.

\section{DRACAENAS}

There is no variety of foliage plant as attractive as the highly-colored Dracaena. The small and medium sizes can be used to great advantage in making up the popular Christmas baskets, while the large specimens have always been in great demand for decorative purposes. We are now growing more Dracaenas, in greater variety, then any firm in this country.

\section{DRACAENA GODSEFFIANA}

Green and white leaf, very hardy; fine for baskets. $21 / 4$-inch pots . . . . . . . . . . . . $\$ 10$ per 100 3 -inch pots.................. \$15 per 100 4 -inch pots................. \$25 per 100

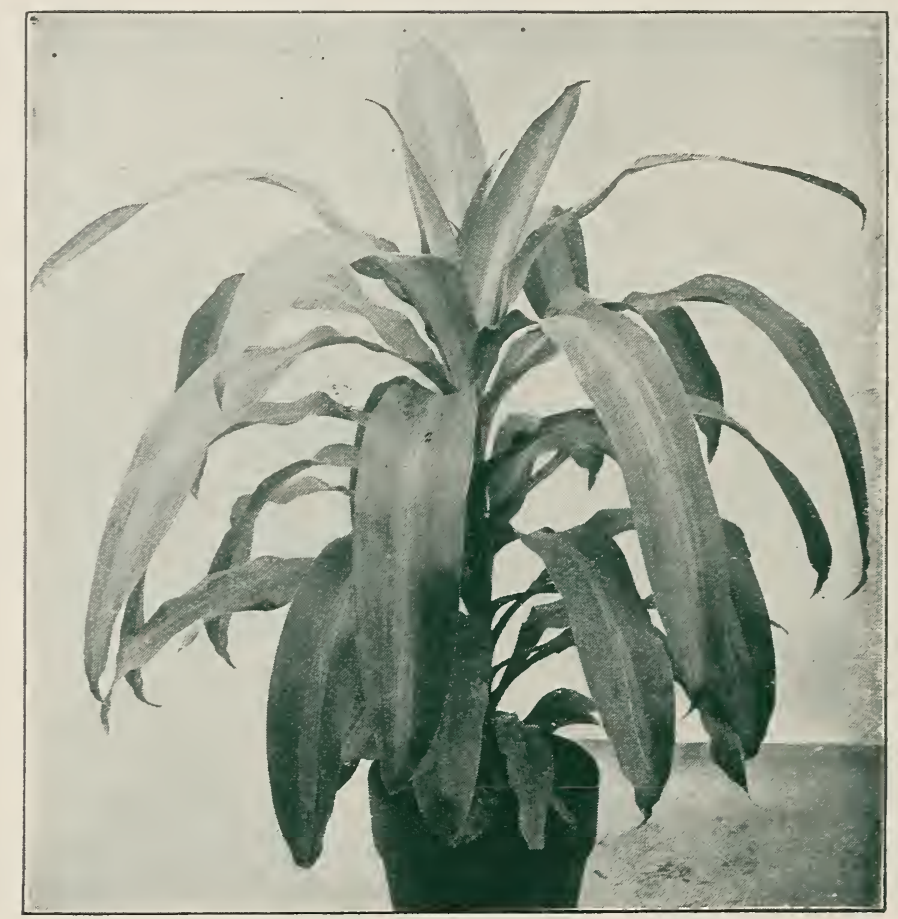

DRACAENA MASSANGEANA

\section{CROTON LEAVES AND SPRAYS}

Cut Croton leaves and sprays have been supplied by us in the past few years to some of the leading retail florists, who have featured them in mantel, table and funeral work. They are also especially attractive to use with Chrysanthemums.

Cut Crotons will last in a cool place from three to four weeks. We can supply them every day in the year. Very highly colored sprays at $25 \mathrm{c}$., $35 \mathrm{c}$. and $50 \mathrm{c}$.

Cut leaves, $\$ 3$ and $\$ 5$ per 100 .

When you have orders for funeral or table work "out of the ordinary," order "Craig's Cut Crotons."

\section{DRACAENA MASSANGEANA}

The variety with the golden stripe down the center of the leaf. This handsome plant is the best of all Dracaenas for the house. We have an exceptionally large stock, well colored, and of the very highest quality.

4-inch pots . . . . . $\$ 7.50$ per doz., $\$ 50$ per 100 6 -inch pots ...........\$15 and $\$ 18$ per doz. 8 -inch pots ............\$2, \$2.50 and $\$ 3$ each 10 -inch pots ............\$3.50, \$4 and $\$ 5$ each

\section{DRACAENA FRAGRANS}

Plain green leaf.

6 -inch pots............. $\$ 6$ and $\$ 9$ per doz. 8 -inch tubs ..................\$18 per doz. 
DRACAENA BRONZE BEAUTY

This variety was offered three years ago with Dracaena Mandaiana by the introduecr, Wm. A. Manda. and is the strongest-growing Dracaena we have. Although not as highly colored as Dracaena De smetiana, we have found it wonderfully durable as a house plant. We offer splendid specimens.

$21 / 2$-inch pots................ \$12 per 100 4 -inch pots . . . . . . . . . . . . \$35 per 100

5 -inch pots . . . . . . . . . . . . . . \$s() per 100

6 -inch pots ............ $\$ 9$ and $\$ 12$ per doz.

Larger specimens.......\$1.50, \$2, \$2.50) and \$3 each

\section{DRACAENA BAPTISTII}

Long, broud foliage, cream, red and orange.

(6-inch pots.

$\$ 1, \$ 1.25$ and $\$ 1.50$ each

\section{DRACAENA AMABILIS}

(ireen and pinkish white; very fine.

3-inch pots.

$\$ 35$ per 100

4-inch pots

$\$ 50$ per 100

5-inch pots

$\$ 9$ per doz

6-inch pots

$\$ 12, \$ 15$ and $\$ 18$ per doz.

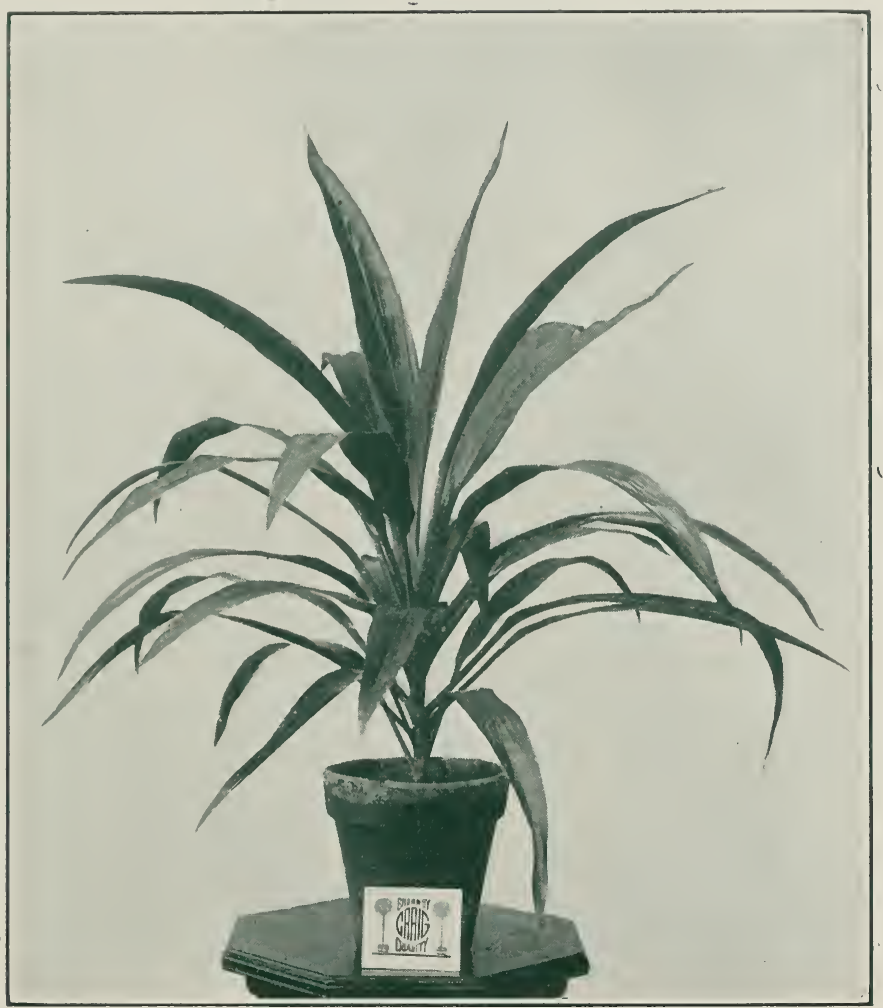

DRACAENA LORD WOLSELEY

\section{DRACAENA LORD WOLSELEY}

One of the very best varieties for Christmas, being bright red in color.

2-inch pots.

$\$ 12$ per 100

3 -inch pots, very heavy . . . . . . . . .\$25 per 100

4-inch pots, very heavy . . . . . . . . . . \$35 per 100

5 -inch pots, very heavy .....\$7.50 and $\$ 9$ per doz. 6 -inch pots, very heavy ......\$12 and $\$ 15$ per doz.

\section{DRACAENA SANDERIANA}

Small, light green leaves, edged with creamy white. Fine for center of fern dishes or basket work. $21 / 2$-inch pots..............\$15 per 100

\section{DRACAENA STRICTA GRANDIS}

Carmine red leaves.

3 -inch pots..................\$35 per 100 4 -inch pots . . . . . . . . . . . . . \$50 per 100 6 -inch pots ............\$12 and $\$ 15$ per doz.

\section{DRACAENA SHEPHERDII}

Carmine and green leaves.

3 -inch pots..................\$35 per 100

4 -inch pots.................\$50 per 100

5 -inch pots................\$9 per doz. 6 -inch pots . . . . . . . . . . \$12 and $\$ 15$ per doz. 


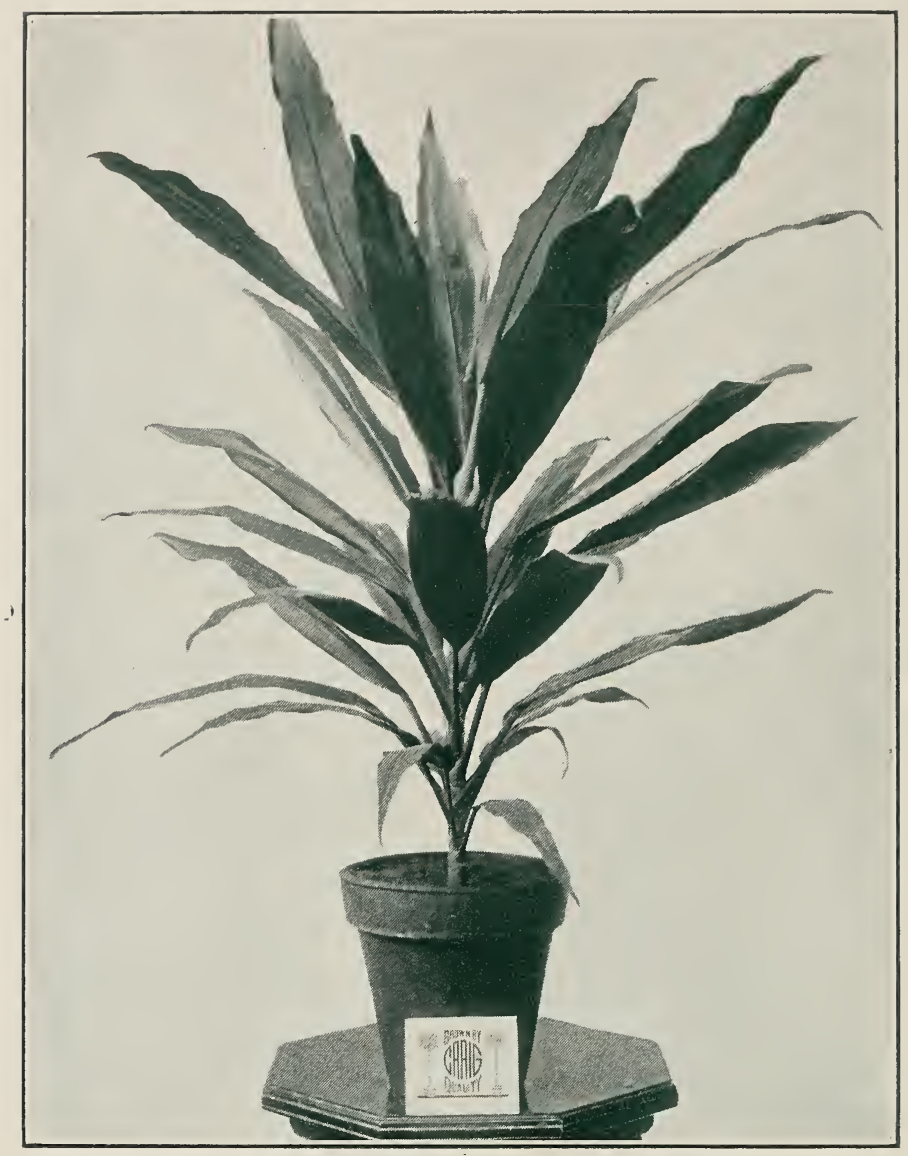

DRACAENA TERMINALIS

\section{DRACAENA TERMINALIS}

Exceptionally well colored.

4-inch pots, strong plants $\$ 30$ and $\$ 35$ per 100 5 -inch pots, strong plant $\$ 50$ and $\$ 75$ per 100 6 -inch pots, extra strong.......\$12 and $\$ 15$ per doz.

We would suggest ordering the above early as the demand is always great. 


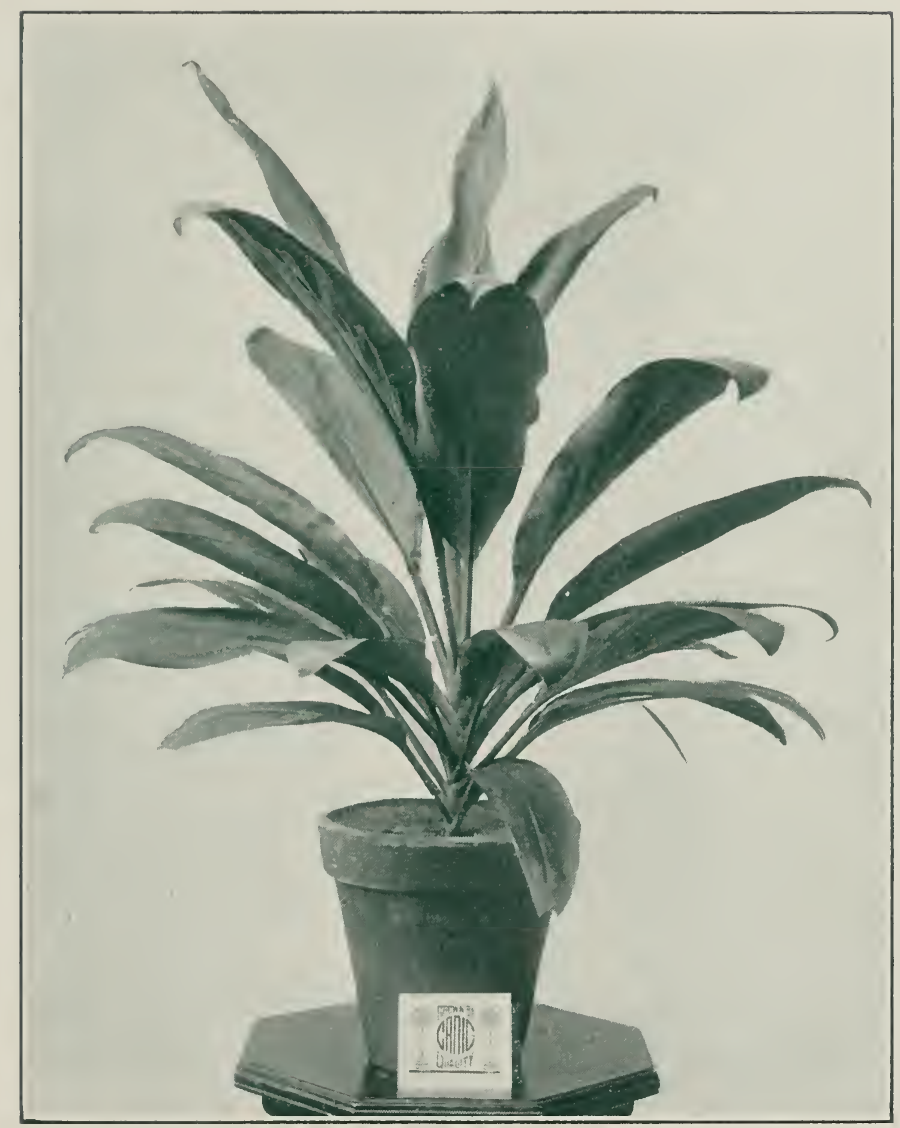

DRACAENA MANDAIANA

\section{DRACAENA MANDAIANA}

Large, bright red leaf, beautifully colored.

3 -inch pots . . . . . . . . . . . . . $\$ 25$ per 100

4 -inch pots . . . . . . . . . . . . . . . . . \$35 per 100

5 -inch pots ................. \$75 per 100

6 -inch pots ............. \$12 and $\$ 15$ per doz. 


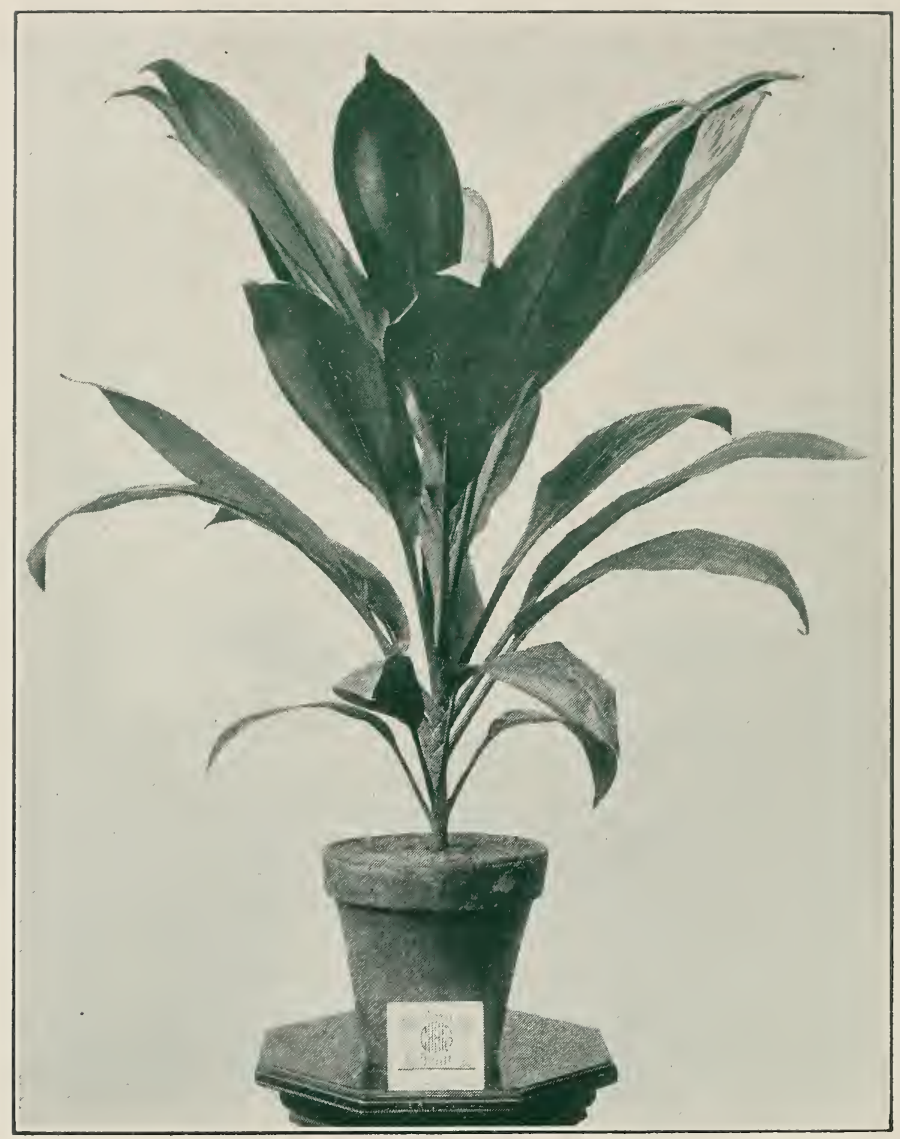

DRACAENA DE SMETIANA

\section{DRACAENA DE SMETIANA}

This is one of the most desirable of the broad leaf varieties; a strong, vigorous grower, with bold, dark green foliage which becomes beautifully suffused and variegated. Our stock is exceptionally fine this fall.

4 -inch pots ................\$0.50 each 5 -inch pots .............\$ $\$ 0.75$ and $\$ 1$ each 6 -inch pots . . . . . . $\$ 1.25$ and $\$ 1.50$ each 


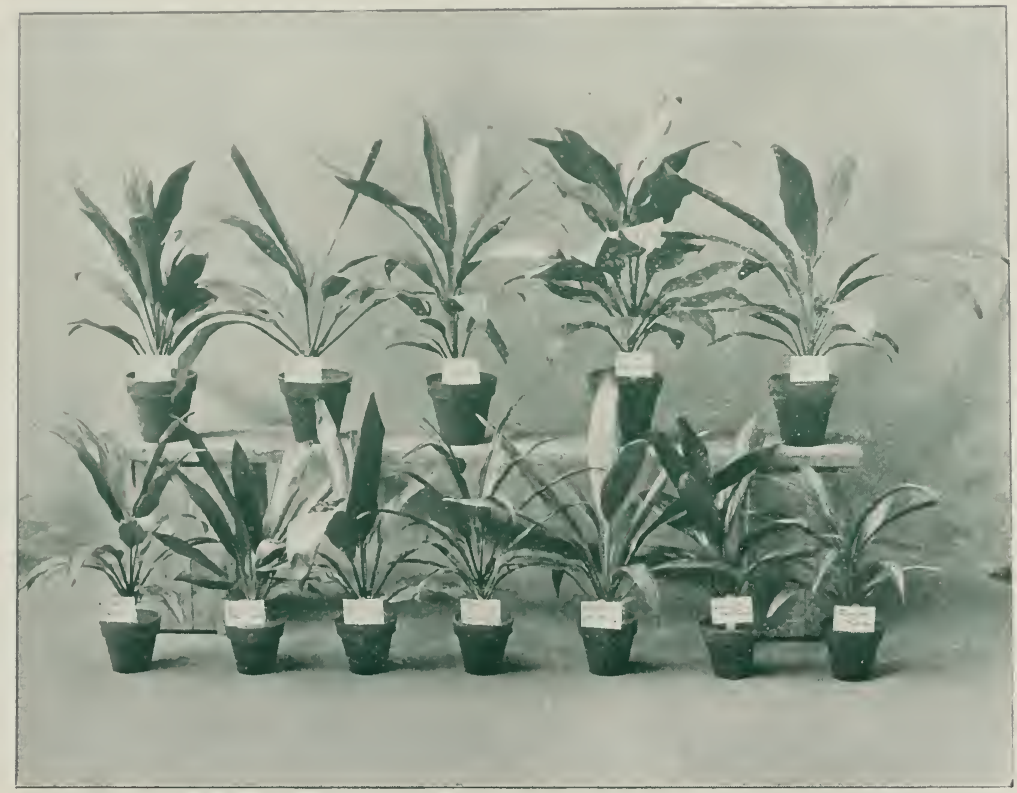

TWELVE NEW AND RARE DRACAENIAS

\section{DRACAENA BRAZILIENSIS (Rare)}

4-inch pots $\$ 35$ per 100 5-inch pots $\$ 6$ and $\$ 9$ per doz.

\section{DRACAENA MME. WINKLEMAN (NeW)}

6 -inch pots........\$12, $\$ 15$ and $\$ 18$ per doz.

\section{DRACAENA GLADSTONE (Rare)}

4-inch pots $\$ 6$ per doz. 5 -inch pots $\$ 9$ per doz. 6-inch pots $\$ 12, \$ 15$ and $\$ 18$ per doz.

\section{DRACAENA GUILFOYLEII（Rare)}

4-inch pots..............\$6 per doz. 5 -inch pots ...............\$9 per doz. 6 -inch pots .........\$12, \$15 and $\$ 18$ per doz.

\section{DRACAENA TITWORTHII (Rare)}

4 -inch pots ...............\$6 per doz. 5 -inch pots . ..............\$9 per doz. 6 -inch pots .........\$12, $\$ 15$ and $\$ 18$ per doz.

\section{DRACAENA SEEDLINGS}

Some beautiful varieties in many colors. 4 -inch pots..................\$5 each

\section{DRACAENA INDIVISA}

Excellent as a decorative plant.

5 -inch pots . . . . . . . . . . . . . .\$20 per 100 6 -inch pots . . . . . . . . . . . . .\$35 per 100 


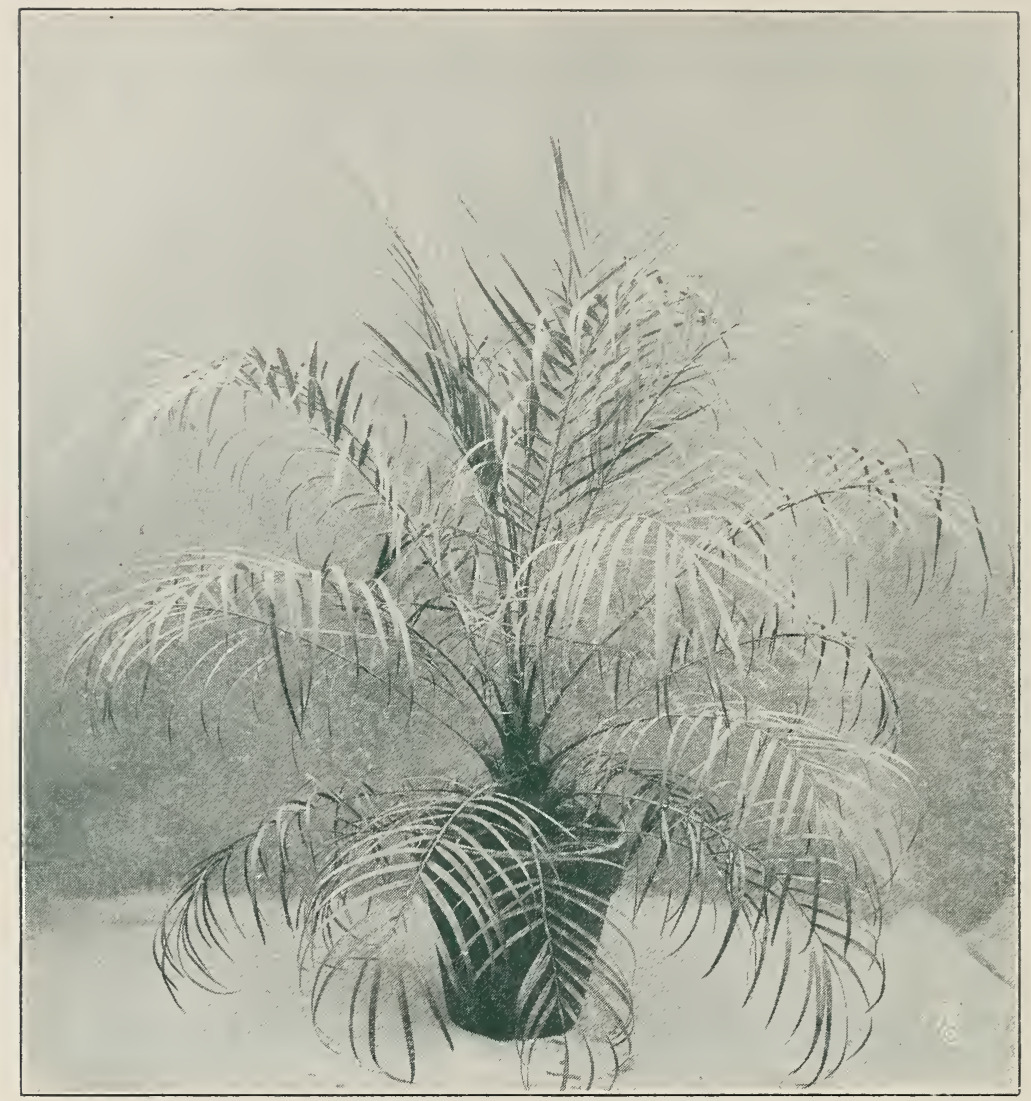

PHOENIX ROEBELENII

\section{PHOENIX ROEBELENII}

This is unquestionably one of the great palms of the future, combining the grace of a Cocos Weddelliana with the hardiness of a Kentia. It will prove an invaluable plant for the house. Our stock in the following sizes is unusually fine.

6 -inch pots............. \$1 and $\$ 1.25$ each 7 -inch pots................... \$2 each 10-inch and 12-inch tubs, specimen plants, $\$ 5, \$ 6, \$ 7.50, \$ 10, \$ 12.50, \$ 15$ and $\$ 20$ each 


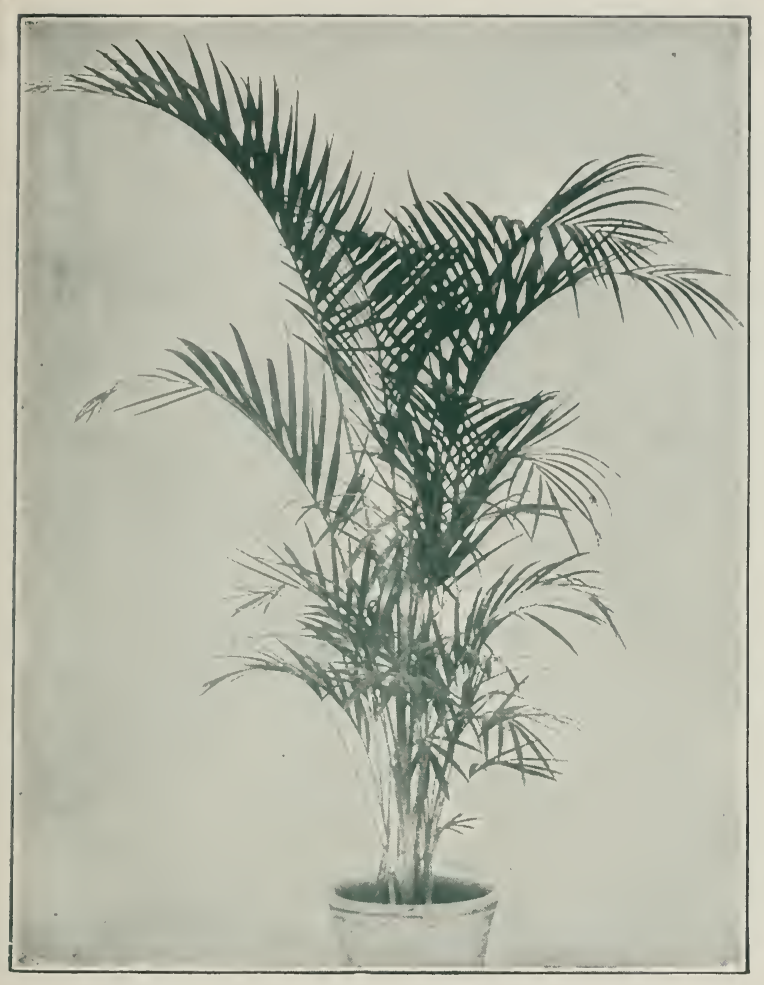

ARECA LUTESCENS

\section{ARECA LUTESCENS}

Perferet plants with rich, dark green foliage. Our stock has been grown cool and hard. It is in splendid condition and will surcly give satisfaction.

t-inch pots, marle up

S2:) per 100

6 -inch pots, made up, 26 to 28 in. tall,

$\$ 12$ per doz. $\$ 90$ per 100 8 -inch pots, made up), very heavy, 36 to 42 in. tall,

$\$ 30$ and $\$ 36$ per doz. 10-inch pots, made up, very heavy, 60 to 66 in. tall,

$\$ 4$ and \$5 cach 10-inch tubs, made up, very heavy, 72 to 80 in. tall,

$\$ 6$ and $\$ 7.50$ cach

\section{KENTIAS}

Kentia Belmoreana and Kentia Forsteriana. 3 -inch pots, 4 to 5 leaves. $\$ 15$ per $100, \$ 140$ per 1,000 6 -inch pots, 3 plants, heavy, 18 to 24 in. tall,

$\$ 9$ and $\$ 12$ per doz

\section{PANDANUS VEITCHII}

Well-colored plants.

$21 / 2$-inch and 3 -inch pots . . . . . . . . . \$30 per 100

4 -inch pots..........\$6 per doz., \$45 per 100

j -inch pots ..........\$9 per doz., $\$ 70$ per 100

6 -inch pots..........\$12 per doz., $\$ 90$ per 100

8 -inch pots...........\$24 and $\$ 30$ per doz.

\section{ARAUCARIA EXCELSA}

5-inch pots, 4 and 5 tiers. . . . \$9 per doz., $\$ 70$ per 100 6 -inch pots . . . . . . . . . . $\$ 12$ per doz.

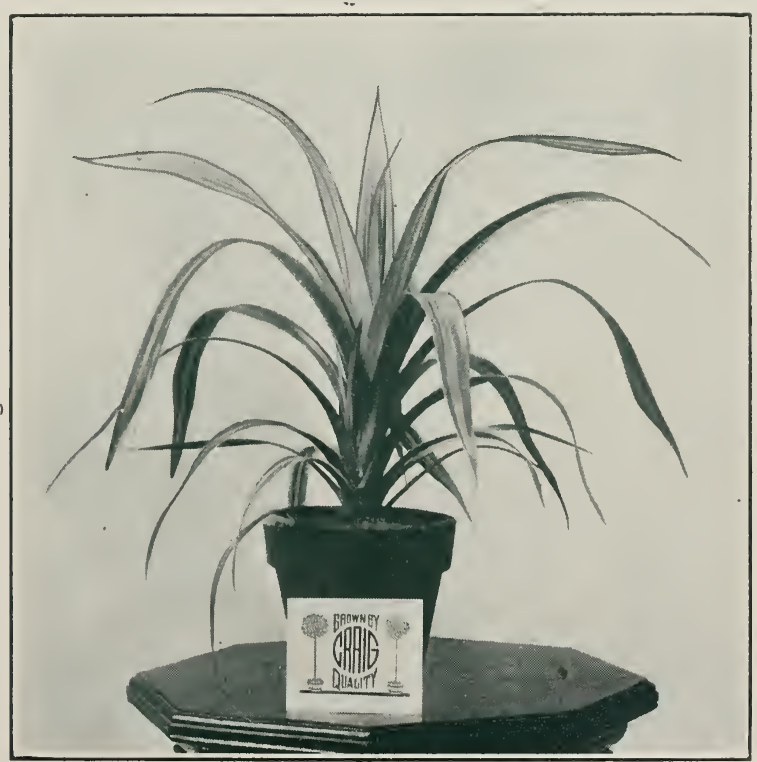

PANDANUS VEITCHII 


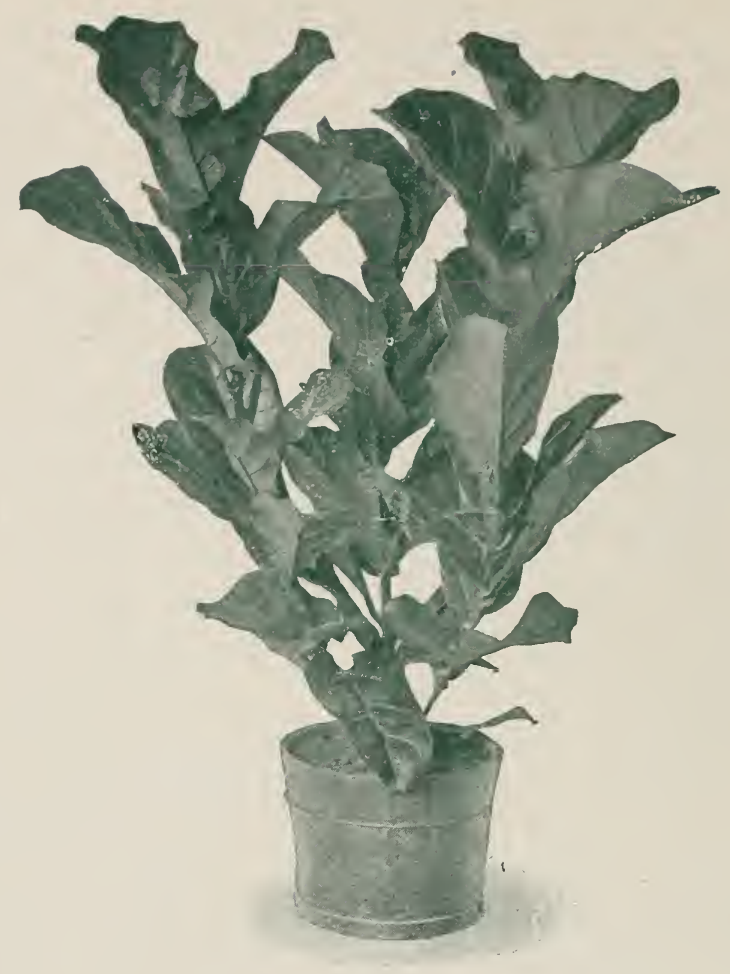

FICUS PANDURATA

\section{FICUS PANDURATA}

The plant of the century. Positively the best house and porch plant to date. Out stock of this wonderful plant this year is finer than we have heretofore offered. It will surely give satisfaction.

6 -inch pots, 2 ft. tall .............\$1.50 each 6 -inch pots, $2 \frac{1}{2} \mathrm{ft}$. tall............. \$2.00 each 7 -inch pots, $3 \mathrm{ft}$. tall............... \$2.50 each 8 -inch pots, $4 \mathrm{ft}$. tall.............\$3.00 each 10 -inch and 11 -inch tubs, $5 \mathrm{ft}$. to $10 \mathrm{ft}$. tall,

$\$ 4, \$ 5, \$ 6$ and $\$ 7.50$ each

Branch plants, exceptionally fine,

$\$ 2.50, \$ 3, \$ 3.50, \$ 4$ and $\$ 5$ each

The large plants are unusually fine.

\section{FICUS CHAUVERII}

This is an old variety taken up again by us. We believe we have the only stock of this variety in the country. It is in a class with the old Ficus Elastica, being very hardy and doing equally as well for both inside and outside decoration. This plant has already given great satisfaction.

6-inch pots, 18 in. high..... \$6, $\$ 9$ and $\$ 12$ per doz. Large plants..........\$1.50, \$2 and $\$ 2.50$ each

\section{BOXWOOD}

We will have an unusually large stock of Boxwood to offer for delivery October 1st. The plants will be in all sizes from the small windowbox size to the large pyramids $5 \mathrm{ft}$. and $6 \mathrm{ft}$. tall.

Write us early regarding our Boxwood. We will send you our lowest quotations.

\section{FICUS UTILIS}

A species that came to us through the Botanical Gardens at Washington, D. C., which promises to be a valuable addition as a decorative house plant. The leaves are thick and leathery, and are from $18 \mathrm{in.} \mathrm{to}$ $24 \mathrm{in}$. long, one half as wide, of a rich, holly-green color, with midrib and veins of an ivory white which stand out prominently.

6 -inch pots, 24 in. tall................\$3 each

\section{FICUS CRAIGII}

This variety is a greatly improved Ficus Elastica and is bound to prove a universal favorite. It is close jointed and the midrib stands out prominently, being ivory-white in color.

4 -inch pots, 15 in. tall.............\$35 per 100 6 -inch pots, 18 in. to 24 in. tall... $\$ 6$ and $\$ 9$ per doz. Large plants............. $\$ 12$ and $\$ 15$ per doz.

\section{CyCAS REVOLUTA LEAVES}

We have on hand large specimen plants of Cycas Revoluta from which we cut the leaves. The natural leaves are far superior to the prepared Southern-grown stock and are being used more each year for the better work by retail florists. We can supply perfect leaves at all times.

Leaves, 36 in. to 42 in. long...........\$3 per pair Specimen plants in tubs...\$20, $\$ 25, \$ 35$ and $\$ 50$ each 


\section{0,000 NEPHROLEPIS - In Variety}

We are the largest growers of Nephrelepis Ferns in the country, in the following varieties; in fact, we are the headquarters for them. The demand increases each year, and it is our aim to have

\section{Every Variety in Nephrolepis in Every Size Every Day in the Year.}

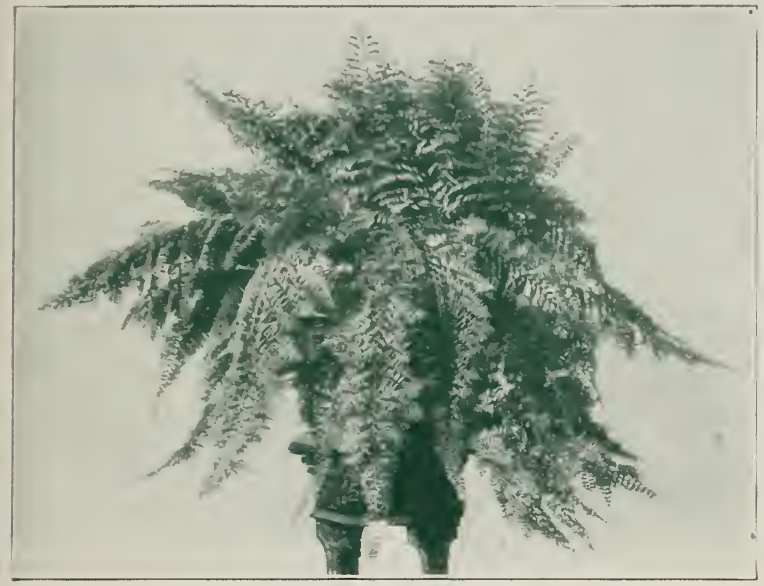

NEPHROLEPIS ELEGANTISSIMA IMPROVED

\section{NEPHROLEPIS TODEAOITES}

London Fern. A good, strong grower and one we think of very highly.

\section{$21 / 4$-inch pots \\ 4 -inch pots \\ 6 -inch pots \\ 8 -inch pots}

9-inch and 10-inch tubs. \$.j per $100, \$ 45$ per 1,000

$\$ 20$ per $100, \$ 180$ per 1,000

$\$ 50$ per 100

.$\$ 12$ per doz.

$\$ 18, \$ 24$ and $\$ 36$ per doz.

\section{NEPHROLEPIS BOSTONIENSES WM. K. HARRIS}

The finest variety for large plants, being a great improvement over the old Boston.

This variety is a greatly improved Elegantissima and shows no tendency to revert to the Boston. This will prove a valuable addition to the crested varieties.

$21 / 4$-inch pots . ........\$6 per $100, \$ 50$ per 1,000

4 -inch pots . . . . . . . . . . . . . \$20 per 100

6 -inch pots ..........\$ $\$ 6$ and $\$ 9$ per doz.

8 -inch pots ...........\$12 and $\$ 15$ per doz.

Large plants............. $\$ 1, \$ 1.50$ and $\$ 2$ each

Largest plants .......\$2, $\$ 2.50, \$ 3$ and $\$ 3.50$ each

\section{NEPHROLEPIS SCHOLZELII}

This is an ideal crested fern, holding the same relation to all other crested varieties that the Scottii holds to the old Boston.

$21 / 4$-inch pots . ......\$6 per $100, \$ 50$ per 1,000

4 -inch pots, heavy ... \$20 per $100, \$ 180$ per 1,000

6 -inch pots, heavy....... \$6 per doz., \$45 per 100

6 -inch pots, very heavy . .\$9 per doz., $\$ 70$ per 100

8 -inch $3 / 4$-pots.........\$12 per doz., $\$ 90$ per 100

10 -inch $3 / 4$-pots..........\$18 and $\$ 24$ per doz.

\section{NEPHROLEPIS AMERPOHLII}

Philadelphia Lace Fern. Beautiful; in all sizes up to 6 -inch.

6-inch pots $\$ 6$ and $\$ 9$ per doz.

. . \$6 per $100, \$ 50$ per 1,000

4 -inch pots $\ldots \ldots \ldots \ldots \$ 20$ per $100, \$ 180$ per 1,000
6 -inch pots $\ldots \ldots \ldots \ldots \ldots 6$ per doz., $\$ 45$ per 100

8 -inch pots ..........\$12 and $\$ 15$ per doz.

11 -inch tubs ......\$2, $\$ 2.50, \$ 3, \$ 4$ and $\$ 5$ each

\section{NEPHROLEPIS BOSTONIENSES HARRISII}

A dwarf type of the Nephrolepis Harrisii and excellent in all sizes from 4 -inch plants up.

$21 / 4$-inch pots $\ldots \ldots \ldots \ldots \ldots \$ 6$ per $100, \$ 50$ per 1,000
4 -inch pots $\ldots \ldots \ldots \ldots . \$ 20$ per $100, \$ 180$ per 1,000
6 -inch pots $\ldots \ldots \ldots \ldots \ldots . \$ 6$ per doz., $\$ 45$ per 100
8 -inch pots . $\ldots \ldots \ldots \ldots \ldots \$ 12$ and $\$ 15$ per doz.

\section{NEPHROLEPIS GIATRASII}

Sport of Neph. Bostonienses. This variety is beautiful in a small plant and will prove a valuable addition as a small fern for pans, etc.

8 -inch pots...........\$15 and $\$ 18$ per doz.

\section{NEPHROLEPIS ELEGANTISSIMA COMPACTA}

A dwarf compact form of Nephrolepis Elegantissima, each plant making an ideal shape.

$21 / 4$-inch pots . . ....... $\$ 6$ per $100, \$ 50$ per 1,000

6 -inch pots...........\$6 per doz., $\$ 45$ per 100

8 -inch pots.............\$12 per doz. 


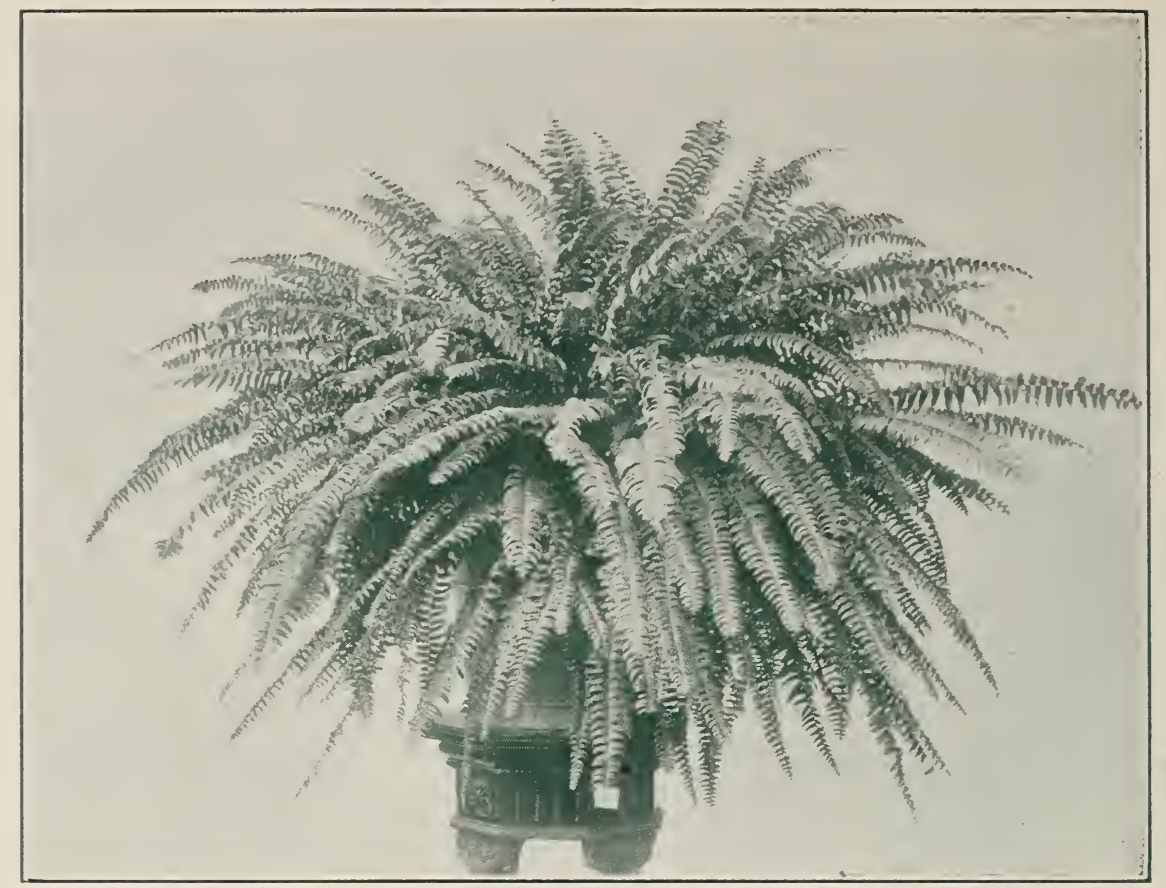

NEPHROLEPIS SCOTTII

\section{NEPHROLEPIS :SCOTTII}

Our stock is in superb condition.

\begin{tabular}{|c|c|}
\hline & \\
\hline -inch pots & er 1,000 \\
\hline & er 100 \\
\hline av! & er 100 \\
\hline ots... & er 100 \\
\hline$h^{3 / 4}$-pots & r doz. \\
\hline & $\$ 2, \$ 2.50$ and \\
\hline
\end{tabular}

\section{NEPHROLEPIS SMITHII}

The greatly improved Amerpohlii. It is a compact form, much finer than Amerpohlii and does not break down in the center. The fronds are carried on wiry stems. This variety will have a wonderful sale up to a 6 -inch pot, being particularly showy for basket work. $21 / 4$-inch pots . . . . . . $\$ 10$ per $100, \$ 90$ per 1,000 4 -inch pots . . . . . . . . . . . . . \$25 per 100 6 -inch pots . . . . . . . . . $\$ 6$ and $\$ 9$ per doz.

\section{NEPHROLEPIS TUBEROSA PLUMOSA}

This beautiful fern is quite distinct from all of the other varieties of the Boston Fern in so much that it has been raised from the Japan species Nephrolepis Tuberosa, which type is much hardier than the Exaltata.

The fronds are long and narrow, the pinnules beautiful plumose which are of light color, giving the fronds a beautiful effect on account of the two distinct shades as well as its graceful waviness, and will be found a great and distinct addition to collection ferns.
$21 / 4$-inch pots
$\$ 15$ per $100, \$ 140$ per 1,000

4 -inch pots

$\$ 25$ per $100, \$ 225$ per 1,000

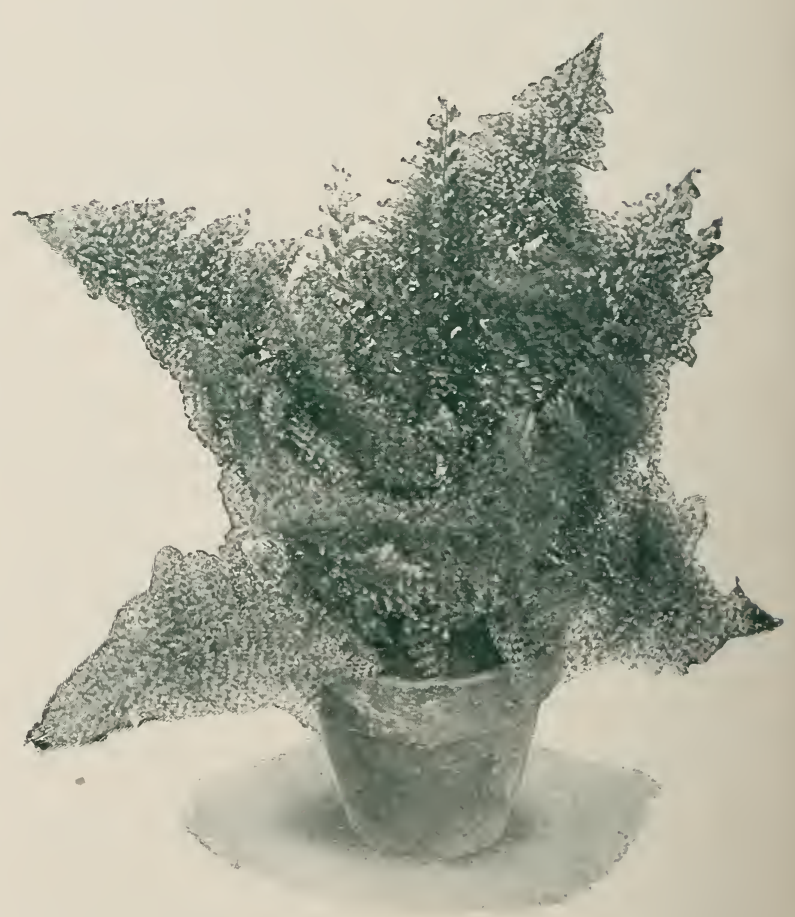

NEPHROLEPIS SMITHII 


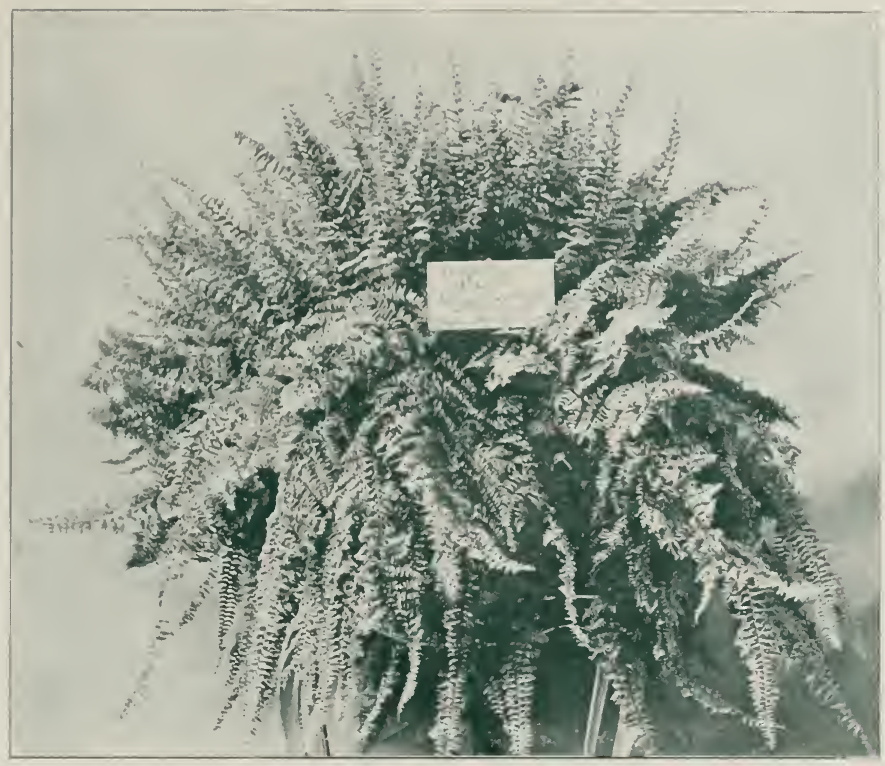

NEPHROLEPIS ROBUSTA

\section{NEPHROLEPIS ROBUSTA (New)}

Place orders at once for Neph. Robusta. The Silver Medal fern at the National Flower Show, winning over all competition. We claim this variety to be the finest of all the crested Nephrolepis, being exceptionally fine in large sizes. It is the strongest grower of all the Nephrolepis ferns, never reverts and every plant is symmetrical and salable in all sizes.

Delivery, August and September, 1913. $21 / 4$-inch pots, strong plants, $\$ 20$ per $100, \$ 150$ per 1,000 4 -inch pots, strong plants,

$\$ 50$ per $100, \$ 400$ per 1,000

\section{ASPARAGUS PLUMOSA NANUS}

3 -inch pots ...........\$7 per $100, \$ 65$ per 100 4 -inch pots . ........\$12 per $100, \$ 110$ per 1,000

\section{ASPARAGUS HATCHERII}

As a grower Asparagus Hatcherii is coming up to all predictions made for it a year ago. It will make more green to the square foot than any variety grown. Its dainty foliage and lasting qualities make it a general favorite.

4-inch pots, heavy . . . . . . . . . . . . \$12 per100

\section{ADIANTUM HYBRIDUM}

The best variety for either a pot plant or for cut fronds.

3 -inch pots, heavy . . . .\$10 per $100, \$ 90$ per 1,000

4 -inch pots, heavy.....\$20 per $100, \$ 180$ per 1,000

6-inch pots, heavy.........\$6 per doz., \$45 per 100

8 -inch pots . . .........\$12 per doz., $\$ 90$ per 100 11 -inch tubs . . . . . . . . . . \$24 per doz.

\section{ASPLENIUM AVIS NIDUS}

Bird's Nest Fern. Plants of exceptional quality. 6 -inch pots............\$12 and $\$ 15$ per doz.
A Grand New Dwarf Fern

\section{"TEDDY JUNIOR"}

"Teddy Junior," the Fern for Every Household. It is a sport from the now famous Roosevelt Fern, and while its habit of growth is to produce a shorter frond it retains all the valuable characteristics of the parent plant. The fronds are broad and beautifully tapered from base to tip; they droop just enough to make a shapely, graceful plant, permitting it to finish with a fine full center and perfect symmetrical spread. The pinnae are distinctly undulated, giving the fronds an attractive wavy appearance, which adds materially to their charming decorative effect, and thin, scraggy foliage is never seen in this variety. "Teddy" will produce about four times more fronds than any other Fern ever introduced, finishing with fifty to sixty fronds in a 4 -inch pot, while twelve to fifteen is the average number other varieties will produce in the same size pot. It is such a compact, rigorous grower that it will thrive under most adverse conditions, making an exceptionally rapid growth and producing a plant of rare beauty and perfection in the average dwelling house without special care or attention. Owing to its habit of producing the great quantity of massive foliage in small pots, this Fern makes the finest pedestal plant ever produced, and will prove indispensable for decorating dining room or library tables and numerous other places in the home where limited space will not permit using large pots or varieties with longer fronds. As a table decoration, fern growers can appreciate the commercial value of a dwarf variety that will produce forty to fifty fronds twelve to fifteen inches long in a 4 -inch pot. Such plants could readily be disposed of and every grower can produce them from "Teddy Junior" with as little care and expense as they can grow other varieties. Ready for June 1st delivery. Fine young plants from 21/4-inch pots ........\$0.40 each, \$3.50 per doz. $\$ 25$ per $100, \$ 200$ per 1,000 


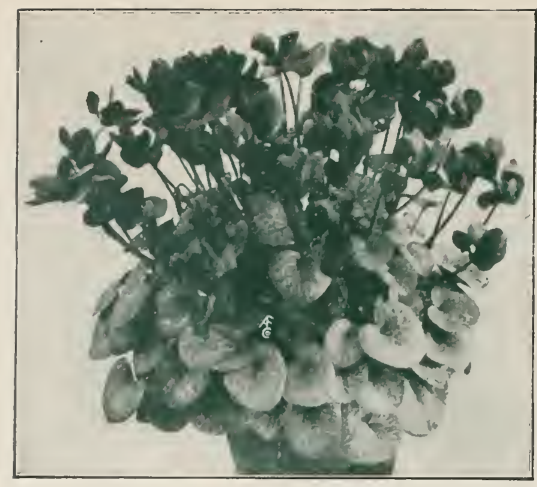

CYCLAMEN

\section{CYCLAMEN}

This has been one of our specialties for over twenty years. This year we grew upwards of 80,000 plants. In all of our experience we have never seen a finer lot of plants. We are growing our stock in new houses. They are absolutely clean and perfect in every way, and not to be compared with weakly-drawn stock offered at less money.

4-inch pots

5 -inch pots

$\$ 25$ per $100, \$ 225$ per 1,000

6-inch pots

$\$ 50$ per $100, \$ 450$ per 1,000

7-inch pots $\$ 75$ and $\$ 100$ per 100

This will be profitable to anyone buying now.

\section{BEGONIA GLORIE DE CHATTELAINE}

The most beautiful of the Veruon type and Lorraine pink in color.

3 -inch pots . ........ $\$ 10$ per $100, \$ 75$ per 1,000

4 -inch pots . ........\$20 per $100, \$ 150$ per 1,000

6 -inch pots . .................. \$35 per 100

\section{GARDENIA VEITCHII}

4 -inch pots, very heavy . . \$20 per $100, \$ 175$ per 1,000 6 -inch pots, very heavy, will flower early,

$\$ 6, \$ 9$ and $\$ 12$ per doz.

Our stock is unusually large and exceptionally fine.

\section{GENISTA RACEMOSA}

A large stock of well-grown plants for growing on. 3 -inch pots, heavy....... \$10 per $100, \$ 90$ per 1,000 4 -inch pots, heavy ...... \$20 per $100, \$ 175$ per 1,000 5 -ìnch pots, heavy......\$35 per $100, \$ 300$ per 1,000 6 -inch pots, heavy......\$50 per $100, \$ 400$ per 1,000 7 -inch pots, heavy................\$75 per 100 Larger plan ${ }^{+}$................ from $\$ 1$ to $\$ 3$ each

\section{HYDRANGEAS}

The new French Hydrangeas. All of the varieties here offered have been tested by us under ordinary conditions as to their adaptability to forcing for Easter. All have proven themselves to be valuable additions. We have over 40,000 strong plants in the following varieties:
Bouquet Rose, bright pink.

Gene de Vibraye, bright rose.

La Lorraine, bright pink.

Mme. a Riveram, bright rose.

Mme. E. Mouillere, best white

Mme. Maurice Hamar, bright pink.

Mme. Renee Gaillard, large white.

Souv. de Mme. E. Chautard, bright rose.

$21 / 4$-inch pots . . . . . . . \$8 per $100, \$ 75$ per 1,000

4 -inch pots.........\$20 per $100, \$ 175$ per 1,000

6 -inch pots .................\$50 per 100

Larger plants .........\$0.75, $\$ 1, \$ 1.50$ and $\$ 2$ each

\section{HYDRANGEA OTASKA}

Pot-grown stock, well-ripened plants.

4 -inch pots, strong.............. \$15 per 100 6 -inch pots, strong, 4 to 6 heads. $\$ 25$ and $\$ 35$ per 100 6 -inch pots, strong, 6 to 7 heads. $\$ 40$ and $\$ 50$ per 100 Larger plants. $\$ 0.75, \$ 1, \$ 1.25, \$ 1.50, \$ 2$ and $\$ 3$ each

Order at once to insure an early start.

\section{ROSES}

We have an unusually large stock of extra strong, pot-grown plants in both the Hybrids and Climbers, which is much better than field-grown plants for forcing. Place orders early. We will reserve and ship when you want them.

Baby Ramblers, 6-inch pots . ........ \$30 per 100 Phyllis, 6-inch pots ................ \$35 per 100 Orleans, 6-inch pots..............\$35 per 100 Sunburst, 2-year-old, 6 -inch pots . . . . . \$ \$60 per 100 Tausendschon, 6 -inch pots..... $\$ 35$ and $\$ 50$ per 100 Tausendschon, larger specimens,

$\$ 0.75, \$ 1$ and $\$ 1.50$ each

Juniata, specimens, 7-inch pots,

$\$ 0.75, \$ 1$ and $\$ 1.50$ each

Hiawatha, 6 -inch pots........ $\$ 35$ and $\$ 50$ per 100

Lady Gay, 6-inch pots........\$35 and $\$ 50$ per 100

Dorothy Perkins, 6-inch pots . . .\$35 and $\$ 50$ per 100

American Pillar, 6 -inch pots . ... \$35 and $\$ 50$ per 100

American Pillar, larger specimens $\$ 0.75$ and $\$ 1.50$ each

Field-grown, extra strong, 2-year-old, home-grown stock. Canes, $6 \mathrm{ft}$. to $10 \mathrm{ft}$. tall. Not to be compared with nursery or imported plants.

Excelsa, new red Dorothy Perkins....... \$25 per 100

Lady Gay and Dorothy Perkins........ \$15 per 100

Tausendschon.................. \$20 per 100

American Pillar, very fine .....\$15 and $\$ 20$ per 100

Hiawatha ..................... \$20 per 100

Juniata (new), very free flowering ......\$20 per 100

Orleans, very heavy . . . . . . . . . . . . \$20 per 100

Phyllis, very heavy .............. \$20 per 100

\section{HYBRID TEA ROSES}

Killarney, Richmond, White Killarney.

Strong 2-year and 3-year-old stock in 6-inch pots, $\$ 35$ per $100, \$ 300$ per 1,000

This is good stock for fall planting or for forcing for Easter. 


\section{CHRYSANTHEMUMS}

Ten rarieties. These will be exceptionally fine for Octoher and November sales.

6 -inch pots $\$ 6$ per doz. 7-inch and 8 -inch pots . . . \$ \$9, \$12 and $\$ 15$ per doz.

Cut flowers from October 1st to December 1st at lowest market prices. We are growing 50,000 eut chrysanthemums and can fill orders of any size, and color, any day. It will pay you to order fresh-cut stock.

\section{THE NEW, CLEAR SCARLET BEDDING}

\section{GERANIUM}

\section{The Best Commercial Novelty for 1914}

\section{" HELEN MICHELL"}

(Name registered with S. A. F. \& O. H.) Seedling Cross Jean Viaud and Alphonse Ricard.

This sterling novelty will be introduced jointly by Henry F. Michell Co., Philadelphia, Pa., and ourselves, and the plants will all be grown by us at our Norwood place where we will be pleased to have you call.

You will find this Geranium has all the good points claimed for it.

"Helen Michell" is semi-double, of the clearest possible shade of scarlet, is early in bloom and produces these continually during the season. It grows compact medium dwarf, with lustrous green foliage and throws up gigantic flower heads continuously; we claim it to have the largest flower heads of any of the bedding Geraniums. The individual blooms measure $21 / 2$ inches across. It is a common occurrence that a single 4-inch pot plant shows 4 fully-open gigantic flower heads, several half open, and more in bud.

We are booking orders that will be filled in rotation from January, 1914.

$21 / 4$-inch pots . . . . . . . . . . . $\$ 2.50$ per doz. $\$ 15$ per $100, \$ 125$ per 1,000

\section{ENGLISH IVIES}

Both the large and small leaf varieties. t-inch pots . . . . . ... $\$ 15$ per $100, \$ 140$ per 1,000 5 -inch pots . ................... \$25 per 100 



\section{The Richmond Tree Tubs}

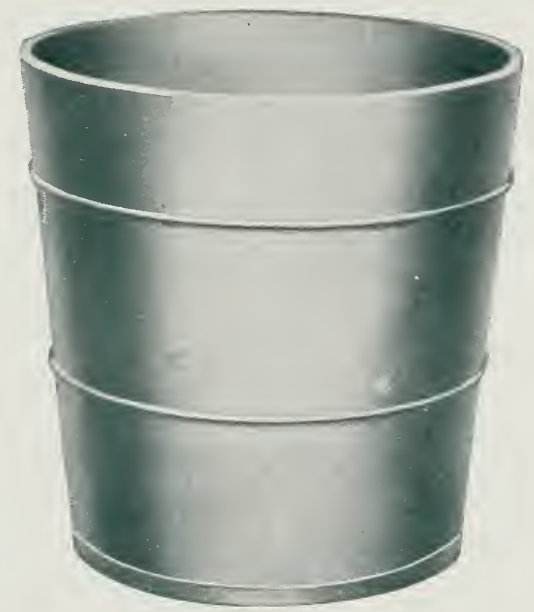

Manufactured for and sold by us in any quantity. The best and cheapest plant tub made; neat, light and durable. Painted green with electric welded hoops.

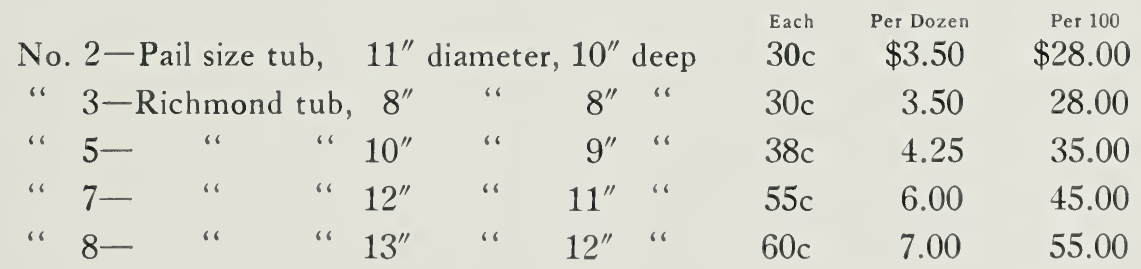




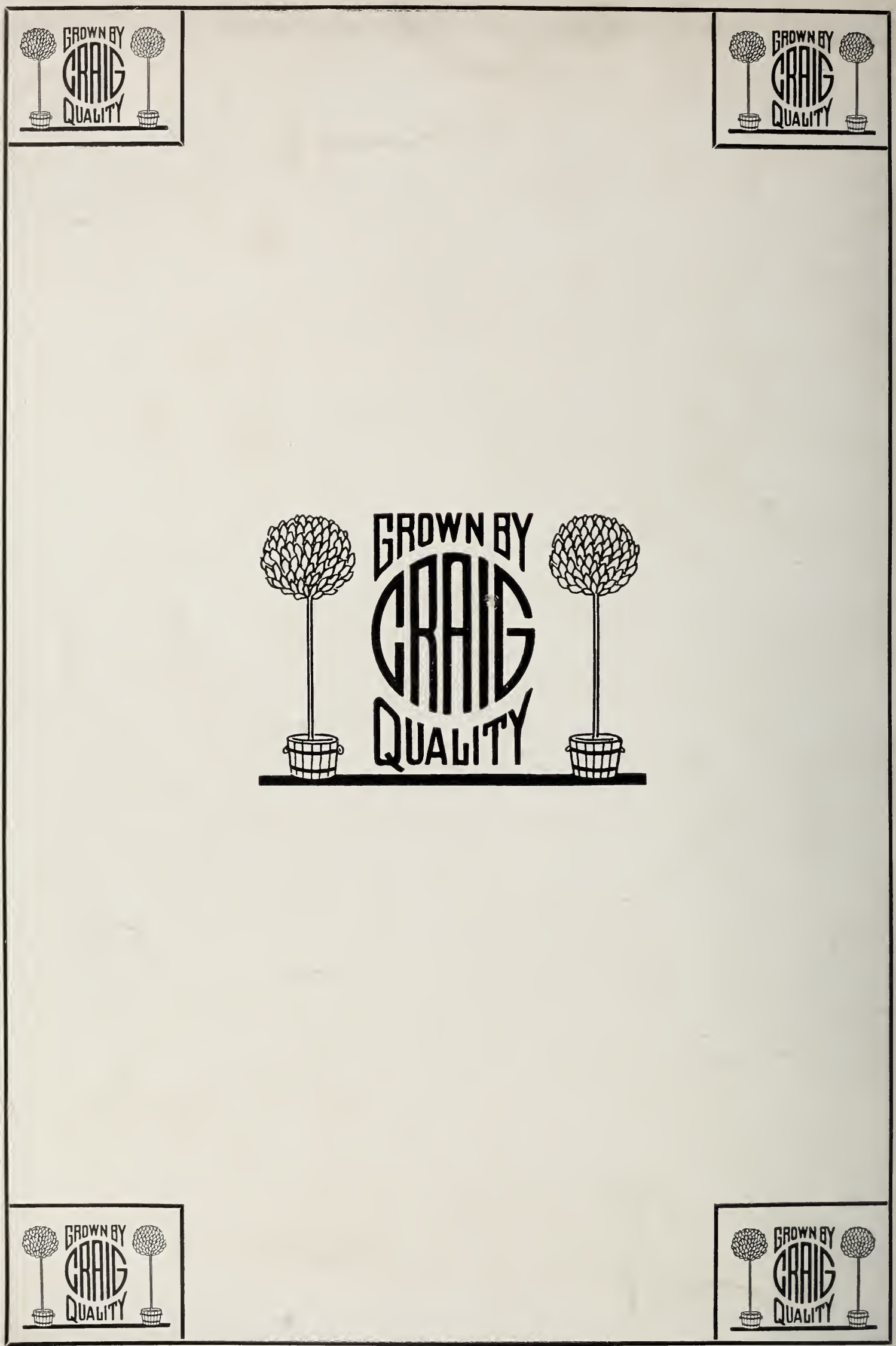

